\title{
An Exploration on Promoting Collaboration of Cultural Creative Industry between Fujian and Taiwan
}

\author{
Guoli Xu \\ Fuzhou University of International Studies and Trade \\ Fujian, China
}

\begin{abstract}
The purpose of this paper is to explore how to positive culture creative industry between Fujian and Taiwan. The paper is consisted of four sections. Firstly, the approach is to review of the literature at domestic and abroad, in order to understand culture creative industrial policy and the definition of culture between Fujian and Taiwan. Secondly, it addressed culture creative industry exchanges and cooperation between Fujian and Taiwan. Thirdly, it evaluated the feasibility of culture creative industrial cooperation between Fujian and Taiwan. Finally, it proposed text and the conclusion and suggestions for decision-making reference.
\end{abstract}

Keywords-culture creative industry; culture between Fujian and Taiwan; collaboration

\section{INTRODUCTION}

Under the administration strategy that governments around the world support the development of cultural and creative industry, Taiwan and mainland are also no exception. In recent years, the cross-strait relations have peaceful development on politics. Besides, consensus is also achieved to develop cultural and creative industry on economy. Therefore, how to cooperate for integration of cultural resources and mutual complementary cooperation of Taiwan and mainland? How to overcome difficulties? How to more effectively exert innovation value of cooperation? They become topics for discussion that deserve exploration and cause one of the motivations of this research.

In policies to Taiwan of our country, General Secretary $\mathrm{Hu}$ Jintao put forward six aspects prior to carry and try the construction of economic zone on the west coast of the Taiwan Straits between Fujian and Taiwan in 2008 and stated that 2010 is the key year. Huang Xiaojing (2010) pointed out the measure of Fujian and Taiwan cooperation prior to carry and try is historic favorable turn. What's the importance and influence of this change? How can cultural creative cooperation between Fujian and Taiwan carry out pioneering steps? This is the second research motivation.

Take Fujian as an example, center on cultural and creative industry to develop animation of culture creativity, radio and television editor, fine arts and clothing and apparel design. At present, management and development of creative talents face many problems. For example, the management and development of creative talents are at lower levels; there are scarce professional creative talents; the structure of professional teacher team loses balance; the way of payment lacks competitiveness. How to break through the dilemma via cultural creative cooperation between Fujian and Taiwan? This is the third research motivation.

Summing up the above motivations, we find the purposes of research are as follows:

- Understand policy and definition of cultural and creative industry between Fujian and Taiwan.

- Discuss exchange and cooperation projects of culture creativity between Fujian and Taiwan.

- Discuss feasibility assessment of cultural and creative industry cooperation between Fujian and Taiwan.

- Suggestions for cultural and creative industry cooperation between Fujian and Taiwan.

\section{LITERATURE DISCUSSION AND DEFINITION OF NOUNS}

\section{A. Fujian and Taiwan and Culture between Them}

According to Wikipedia, Fujian and Taiwan refer to Taiwan and southern Fujian. Southern Fujian series refer to three prefecture-level cities in Fujian province, Zhangzhou, Quanzhou and Xiamen. In broad sense, southern Fujian also includes Putian and also refers to Jiulong River and Jinjiang River basin in southern Fujian. In broader sense, Western Taiwan Straits Economic Zone: Take Fujian as the main part, face Taiwan, close to Hong Kong and Macao, with Yangtze River delta in the north and Pearl River Delta in the south, mainland in the west and cover perimeter zone. It is the economic area with characteristics of its own, unique advantages, radiation agglomeration and objective existence. Shao Longmei (2010) thought the composition of culture between Fujian and Taiwan integrates linkage of five relationships, namely: the geographical relationship is close; the blood relationship is close; the cultural relationship passes on from one to another; the commercial relationship communicates with each other; the law relationship is corresponding. That is to say, it is the integration of geographical relationship, blood relationship, cultural relationship, commercial relationship and law relationship. 


\section{B. Cultural and Creative Industry}

In terms of cultural and creative development policy of various countries in the world, the earliest is creative industry promoted by Prime Minister Blair of UK. In Britain, they call cultural and creative industry as creative industry. The key is brain and creativity. The core is originality. Intellectual property is the only lifeblood. Different from other industries that originality is a part of productive process. At present, comparatively famous countries in the world for the promotion include Britain, South Korea, the United States, Japan, Finland, France, Germany, Italy, Australia, New Zealand, Denmark, Sweden, Netherlands, Belgium and Switzerland. Strategies and strong points of various countries in the world in developing cultural and creative industry have historical origin and national characteristics that conform to their national conditions, shown in the following "Table I".

TABLE I. STRONG POINTS OF CULTURAL AND CREATIVE INDUSTRY IN VARIOUS COUNTRIES

\begin{tabular}{|c|c|c|}
\hline Country & $\begin{array}{c}\text { Strong points of cultural and } \\
\text { creative industry }\end{array}$ & Representative \\
\hline France & $\begin{array}{l}\text { Fashion products and clothing of } \\
\text { hundred-year brands }\end{array}$ & HERMÈS、CHANEL \\
\hline USA & Film industry & Hollywood \\
\hline $\begin{array}{l}\text { South } \\
\text { Korea }\end{array}$ & $\begin{array}{l}\text { Media contents }\lceil\text { film and } \\
\text { television, video game }\rfloor\end{array}$ & Dae Jang Geum-episode \\
\hline Japan & $\begin{array}{l}\text { Content industry }\lceil\text { cartoon and } \\
\text { videogame }\rfloor\end{array}$ & Popular cartoon works \\
\hline
\end{tabular}

In report on the work of the government in two sessions in 2010, China's Premier Wen Jiabao of the State Council listed cultural construction and cultural innovation as developing focuses. Similarly, administrative council of Taiwan also launches many related policies. Firstly, it published cultural and creative industry was one of the six important emerging industries in 2009. In 2010, the Legislative Yuan passed "Cultural and creative industry Development Law". In recent years, (Jiao Fa (2015) No. 7), in regard to Notice of Eight Measures of Fujian Provincial People's Government on Promoting Culture Creativity and Design Service and Integrative Development of Related Industries, according to the spirit of documents from Ministry of Education, National Development and Reform Commission and Ministry of Finance, Instruction Opinion on Guiding Part of Local Average Four-year Colleges to Change into Applicationoriented Type and (Min Zheng (2015) No. 46) Some Opinions of Fujian Provincial People's Government to Accelerate Development of Modern Vocational Education, they require to make clear arrangement of transformational goal, construction mission, reforming measures, resource allocation and fund procurement in school education career planning; formulate transformation development plan of this school, define aims and tasks of critical nodes such as talent training program, major setup, course system, teacher staffing and teaching management mechanism.

In the aspect of Hong Kong, Arts Development Council mentioned creative industry in 1990, which caused news reporting of media; in 2002, Trade Development Council published report on creative industry; in 2003, Central Policy Unit entrusted Centre for Cultural Policy Studies of University of Hong Kong to carry out baseline study of creative industry in Hong Kong; in 2005, the chief executive Mr. Dong Jianhua pointed out in command paper: Accelerate the promotion of cultural and creative industry, establish consulting framework as soon as possible, widely invite industrial circle and cultural circles to jointly participate in discussing development vision, direction and organizational structure of cultural and creative industry in Hong Kong, research on comprehensively exploiting the advantages to the full, integrate resources and carry out key promotion; then chief executive Mr. Zeng Yinquan also brings creative industry in administrative program. At present, policies related to creative industry is in the charge of Home Affairs Bureau and Commerce Industry and Technology Bureau. So far, the government still hasn't a set of policies to comprehensively promote the development of creative industry.

Various countries in the world have different definition on cultural and creative industry. It is also called cultural industry, creative industry and content industry, etc. In Taiwan, it still belongs to emerging industry. Its concept and form remain to be formed and wait for academic research and arrangement. The authority in Taiwan names it as Cultural and Creative Industry. This article takes definitions of UNESCO, Executive Yuan in Taiwan and scholars from Hong Kong as reference basis. Related definitions and national policies are narrated as follows respectively.

In the aspect of the United Nations: The UNESCO defines cultural industries are suitable for contents with intangibility and culture as essence. The industries in combination of creation, production and commoditization can be regarded as creative industries, sunrise or future oriented industries or content industries. UNESCO thinks the concept of cultural industries generally includes: printing, publishing, multimedia, audition and vision, photography and film production, which are equal to crafts and design. For some countries, this concept also includes architecture, visual and performing arts, sports, manufacture of music instruments, advertising and cultural tour. UNESCO mainly divides cultural and creative industry into cultural product, cultural services and intellectual property: Cultural products refer to books, magazines, multimedia products, software, record, film, videotape, audio and video entertainment, technology and fashion design; cultural services include performing services (theatre, opera house and circus), publishing, and publication, news and newspaper, transmission and construction services, audio-visual services (film sales and distribution, TV/radio programs and home video, film exhibition, cable, satellite and broadcasting facilities or ownership and operation of movie theatre), library service, archives, museums and other services.

In the aspect of Taiwan: The term of cultural and creative industry was first defined by the Executive Yuan in May, 2002. The definition of cultural and creative industry: It is the industry that originates from creative or cultural accumulation, penetrates the route and application of intellectual property and has the potential to create wealth and employment opportunity and promotes overall life cultural environment (Council for Cultural Affairs 2002). In February 3, 2010, it made and published "Cultural and Creative Industry Development Law". This law defines cultural and creative industry refers to legal 
person, partnership, sole proprietorship or individuals that work on cultural and creative industry. It also stipulates that in order to cultivate talents of cultural and creative industry, the government shall fully develop and apply human resources of culture creativity, integrate a variety of teaching and research resources, encourage cultural and creative industry to carry out the cooperative research of industry, official and university as well as talent training. The government should assist local agencies, institutes of higher education and cultural and creative industry to enrich culture creative talents and encourage them to establish development facilities related to cultural and creative industry, open relevant courses, or implement creative development, experiment, creation and performance. This law defines cultural and creative industry refers to the industry that originates from creative or cultural accumulation, penetrates formation and use of intellectual property and has the potential to create wealth and employment opportunity and promotes aesthetic accomplishment of the whole people and national living environment. It stipulates that in order to promote the development of cultural and creative industry, the government shall donate to set up legal body of financial group cultural and creative industry development research institute and devote to developing cultural and creative industry and guarantee the expenditure required by its development. The National Development Fund shall invest a certain percentage of capital in cultural and creative industry.

In the aspect of Hong Kong: Xu Zhuoquan in University of Hong Kong (2003) defined cultural industries as an economic activity group that exploits and uses originality, technology and intellectual property to produce and allocate products and services with social and cultural significance and it is expected to become a production system to create wealth and employment. The creative industry in Hong Kong includes eleven industry categories: advertising, architecture, art, antique and crafts, design, digital entertainment, video and film, music, performing arts, publishing and printing, software and electronic calculation as well as television and broadcasting station.

It can be inferred from the above literatures that in order to develop cultural and creative industry, except for coordinating with government policies, taking advantage of opportunity and actively striving for subsidy, it shall discuss value creation, find out the advantages that conform to national conditions as well as projects that can meet the market requirements of consumers.

\section{Projects Suitable For CUltural AND CREATIVE INDUSTRY COOPERATION BETWEEN FUJIAN AND TAIWAN}

Analyzing cultural and creative industry at home and abroad in recent years, it is found that there are numerous types of living examples of culture creativity. The research bases on the following types put forward by Peter Drucker (2011), sorts and develops projects suitable for cultural and creative industry cooperation between Fujian and Taiwan. It shows in the following "Table II".
TABLE II. COOPERATION Projects of CUltural AND CREATIVE INDUSTRY BETWEEN FUJIAN AND TAIWAN

\begin{tabular}{|l|l|}
\hline \multicolumn{1}{|c|}{$\begin{array}{c}\text { Types of culture } \\
\text { creativity }\end{array}$} & $\begin{array}{c}\text { Cooperation projects of cultural and creative } \\
\text { industry between Fujian and Taiwan }\end{array}$ \\
\hline $\begin{array}{l}\text { 1. combining literature } \\
\text { and history }\end{array}$ & $\begin{array}{l}\text { 1. cultural monuments, buildings and heritage, } \\
\text { history }\end{array}$ \\
\hline $\begin{array}{l}\text { 2. combining different } \\
\text { industries }\end{array}$ & $\begin{array}{l}\text { 2. art and literature, science and technology, } \\
\text { education, catering, leisure tourism, sightseeing } \\
\text { and exercise }\end{array}$ \\
\hline $\begin{array}{l}\text { 3. combining local } \\
\text { landscapes }\end{array}$ & 3. scenic spots, sightseeing, leisure and vehicle \\
\hline $\begin{array}{l}\text { 4. combining local } \\
\text { ethnic groups }\end{array}$ & $\begin{array}{l}\text { 4. character, custom, clothes and ornaments, } \\
\text { language and religion }\end{array}$ \\
\hline $\begin{array}{l}\text { 5. combining local } \\
\text { crafts }\end{array}$ & $\begin{array}{l}\text { 5. handcraft, art and literature, performance, } \\
\text { paintings and drawing }\end{array}$ \\
\hline $\begin{array}{l}\text { 6. combining special } \\
\text { local products }\end{array}$ & $\begin{array}{l}\text { 6. agricultural products, aquatic products, special } \\
\text { local products, food and catering }\end{array}$ \\
\hline $\begin{array}{l}\text { 7. combining space } \\
\text { construction }\end{array}$ & $\begin{array}{l}\text { 7. residence, furniture, daily necessities, living } \\
\text { utensils, audio video and digital science and } \\
\text { technology }\end{array}$ \\
\hline $\begin{array}{l}\text { 8. combining local } \\
\text { industries }\end{array}$ & $\begin{array}{l}\text { 8. animation, radio and television editor, fine } \\
\text { arts, clothing and apparel design }\end{array}$ \\
\hline
\end{tabular}

IV. ASSESS FEASIBILITY OF CULTURAL AND CREATIVE INDUSTRY COMMUNICATION BETWEEN FUJIAN AND TAIWAN

\section{A. Advantages and Difficulties of Cooperation and Development of Cultural and Creative Industry between Fujian and Taiwan}

The circulating and integration of resource factors of cultural and creative industry between Fujian and Taiwan is the integration of comparatively rich factors in Taiwan such as innovation, originality, intelligence capital, market experience, marketing channel and organizations and relatively rich factors in Fujian such as cultural resources, labor force and market requirements. The circulating and integration of resource factors of cultural and creative industry between Fujian and Taiwan can improve allocation efficiency and innovate in competitiveness of regional cultural and creative industry. The cultural and creative industry in Taiwan will expand space for survival and development, promote structural transformation and upgrading. The cultural and creative industry in southern Fujian will accelerate structure optimization and industrialization development and promote overall quality and competitiveness. Secretary General Yang Du (2009) of Taiwan Cultural Association thought with economic rise of Chinese Mainland, Chinese culture will have increasingly big influence in the world. Taiwan and mainland complement each other to a very large extent in the field of cultural and creative industry. The mainland has big market, abundant capital and clear policy orientation but lack originality; while Taiwan has the advantage of originality but cannot form scale effect because of small market. Therefore, Taiwan and mainland can achieve the effect of making up for each other's deficiencies and learning from each other.

Taking this opportunity to develop cultural and creative industry that makes Taiwan move from manufacturing economy to creative economy, it is found that there are three advantages for Taiwan to develop cultural and creative industry.

- Taiwan has profound Chinese culture; the history of Taiwan is influenced by immigrant culture of 
Netherlands, Spain and Japan and American culture; it has the beauty that integrates eastern and western cultures.

- Educational system in Taiwan is relatively free and open; there are spaces of creation to design and imagination.

- Taiwan has comparatively rich innovation, originality, intellectual capital, market experience and marketing channels.

The development of cultural and creative industry also needs lateral support of other industries. South Korea and Japan hope to use communication industry such as network construction to enlarge marketability and popularization of cultural and creative industry. However, at present, Taiwan government doesn't have this thinking of lateral industrial integration.

Disadvantages for Taiwan to develop cultural and creative industry are shown as follows.

- Liu Weigong (2010) pointed out through research that the development process of cultural and creative industry in Taiwan is very complicated. It is a very difficult challenge to completely master the appearance of industrial development.

- To take root and develop, it faces difficulties of international competitiveness, lacks market mechanism, lacks long-term, systematic data collections at all levels, cumulative research result and discourse analysis, tens of thousands to several hundred million capital structure in all sectors of the industry, great differences with development environment.

- In education system of credentialism, there isn't systematic and widespread cultivation of art or aesthetics. The basic problem of this kind of education makes consumers have insufficient recognition. They think cultural and creative industry is extra consumption instead of efficient instrument for competition, which cause the restriction and shrink of cultural and creative industrial market in Taiwan.

\section{B. Practice that Fujian and Taiwan prior to Carry and Try}

This article advocates the cooperative localization between Fujian and Taiwan shall start from Taiwan with cultural and creative industry as the originality, make overall arrangement for the mainland and integrate with international convention, let the beauty of Chinese culture carry forward, meanwhile, let cultural and creative industry become engine of industrial revolution of knowledge economy to realize social life with culture creativity and aesthetics. The cooperation model of cultural and creative industry between Fujian and Taiwan develops along with the development of cultural and creative industry cooperation between Fujian and Taiwan. The future research direction of cultural and creative industry cooperation between Fujian and Taiwan is explained as follows.
- $\quad$ stipulate source of law of cultural and creative industry between Fujian and Taiwan and unify terms;

- sign exchange and cooperation agreement of cultural and creative industry between Fujian and Taiwan;

- regularly hold cultural creativity forum between Fujian and Taiwan or cultural creativity expo between Taiwan and mainland;

- strengthen cooperation and communication of production and study between Fujian and Taiwan.

\section{CONCLUSION AND SUGGESTIONS}

By means of creative design of Taiwan, combine inherent culture between Fujian and Taiwan and integrate cultural and creative industry with other industries to highlight life aesthetics concept of Chinese culture and shape unique life style of Chinese people. Plan combination of culture, originality and design between Fujian and Taiwan and vocational education in universities and create new model of combination of production with teaching and strategy, in order to promote opportunity for cooperation and development of cultural and creative industry between Fujian and Taiwan. Promote development of cultural and creative industry, assist dealers to carry out brand market and expand access of international market, plan a series of international exhibitions, integrate and market products of cultural and creative brand to promote image of culture creativity between Fujian and Taiwan. The cooperation and development course of cultural and creative industry between Fujian and Taiwan is suggested to be implemented in four stages respectively.

\section{A. Initial Stage}

The exchange and cooperation of cultural and creative industry between Fujian and Taiwan is mainly implemented among the people. It develops along with the promotion of spontaneous tentative investment of people and academic exchange. Invite people from fields of industry, government, school and scientific research to put heads together, inject new thinking direction and motivation, and assist development of cultural industry. This is to establish cultural and creative industry association.

\section{B. Testing Stage}

As the platform for people from all walks of life and government to voice opinions and integrate, with academic exchange as the guidance, further close relationship of cultural and creative industry between Taiwan and mainland, semiofficial characteristic groups and academies that promote the cooperation and exchange between Taiwan and mainland begin to establish and play the role of bridge and link. They fully learn international school-running experience in Taiwan and deeply integrate higher education resources in both sides of the Taiwan Straits and realize cooperation in running schools of universities between Fujian and Taiwan. The construction contents of school transformation include: talent cultivation, teaching staff, key curriculum, practice base and quality guarantee system. 


\section{Developmental Stage}

It is the platform to provide experience sharing and coach newly-rising enterprises. The selected principle of cultural and creative industry is large number of employees or participants, large production value or big associated benefits or big growth potential, high originality or high innovation and high added value. For test zone of policy innovation and cooperation, Office of the State Council towards Taiwan approves Fuzhou and Zhangzhou to establish "Mainland and Taiwan Cultural and Creative Industry Cooperation Test Zone" as the opportunity to give play to effective demonstration effect.

\section{Expanding Stage}

Pool the wisdom and efforts of everyone to make international planning. On the basis that cooperation test between Fujian and Taiwan achieves remarkable effect, our country approves the "Mainland and Taiwan Cultural and Creative Industry Cooperation Test Zone" of Fujian to expand to the whole province, in order to promote size, scope, field and level of cultural and creative industry cooperation between Fujian and Taiwan to carry forward continuously.

\section{REFERENCES}

[1] Zhu Boyong. 2008, "Value Creates DNA: Innovation in the Future", Who is the Most Innovative in 2008, Janaury.

[2] Jiang Yiwei. 2005, "Research on Influence of Social Capital on Value Creation of Knowledge Circulation and Culture Creativity Business Circle-Take Yingko Ceramics as an Example", master's thesis of Fu Jen Catholic University.

[3] Chen Xiao. 2008, "Research on Value Creation Strategy of Digital Repository Manufacturers and Core Research", master's thesis of Shih Hsin University.

[4] Xiao Jialing. 2009, "Value Creation Strategy of Culture Creative Company-House of Value Opinion", master's thesis of Shih Chien University. 